\title{
STATUS OF FERTILIZER AND SEED SUBSIDY IN NEPAL: REVIEW AND RECOMMENDATION
}

Diwas Raj Bista ${ }^{1}$, Sujan Dhungel ${ }^{2}$ and Santosh Adhikari ${ }^{3}$

\begin{abstract}
The study focuses on the review of existing programs and policies regarding input subsidy in Nepal especially in seeds and fertilizers. The study aims to review timeline in subsidy programs, budget details and progress based on the gleaning of the secondary information available in the Ministry of Agricultural Development. The assured budget allocation for chemical fertilizers subsidy has led to increment in consumption over the years. Nepal spent 52.29 billion Nepali Rupees in importing chemical fertilizers and 23.19 billion in subsidy in last seven years. Nepal Government has also been promoting organic fertilizers however, the subsidy allocated to this program has not been able to take the pace. Seed subsidy program has been found to be impressive; however, it is confined to wheat and paddy only. The subsidy program is targeted mainly to the small and marginal farmers. The seed subsidy program should be expanded to pulses and oilseed crops as well. The organic fertilizers should be promoted to maintain long-term soil health. Inputs subsidy policy and programs should cover all farmer categories.
\end{abstract}

Key words: Subsidy, chemical fertilizer, organic fertilizer, seed,subsidy

\section{INTRODUCTION}

Nepal predominantly is an agricultural country with 3.8 million (70 percent) farmer household (CBS, 2012, CBS, 2013). Agriculture sector contributes about one third (33.09 percent) share in Gross Domestic Product (MoF, 2014).

Nepalese agriculture is characterized by dominance of small and marginal farm holders following traditional and indigenous farming technology which is regarded as low yielding technology. Over the last 10 years, population has been increasing at 1.35 percent annually (CBS, 2012) while agricultural land has decreased by 129 thousands hectares (CBS, 2013). Increasing population coupled with declining agricultural land and stagnant productivity of major cereals has lead to food and self insufficiency in some districts of the country. 31 out of 75 districts were reported to be experiencing self-insufficiency in food production (MoAD, FAO \& WFP, 2014).

Fertilizer, seed and irrigation are major inputs for agricultural production. APP has mentioned that about half of the incremental output can be attributable to increased fertilizer use while National Seed Vision (2013-2025) states that improved seed can contribute 20-30 percent increment in crop yield. Inadequate access of farmers to seed and fertilizer has been identified as major contributing factor for the low production and productivity of agricultural commodities. MOAD aims to achieve food security by increasing agricultural productivity through assured supply of quality inputs. MoAD has been implementing fertilizer and seed subsidy program with special focus on small and marginal farmers.

The Agriculture Perspective Plan (APP, 1995-2014) has envisaged an increase in fertilizer use from 31 $\mathrm{kg}$ nutrient/hectare in the base year (1995) to $131 \mathrm{~kg}$ nutrient/hectare by 2015. Similarly, Agriculture Development Strategy (2015-2034) has also highlighted the low use of fertilizer as the major reason for low productivity and commercialization. It has envisaged the implementation of voucher system for the effective extension service delivery and input supply including fertilizer. As

\footnotetext{
${ }^{1}$ Senior Agri-economist, MoAD, bistadiwas@gmail.com Mobile: 9845091509 Corressponding: bistadiwas@gmail.com

${ }^{2}$ Agriculture Extension Officer, MoAD, sujn.dhungel@gmail.com Mobile : 9851176126

${ }^{3}$ Agri-economist, MoAD, santoshadhikari80@gmail.com Mobile : 9841787274
} 
the majority of Nepalese farmers are small and marginal, characterized by low purchasing power of costly fertilizer, adequate and timely supply of quality fertilizer has been the priority of Government of Nepal (GoN). The agricultural Inputs Management Section (AIMS) under ministry is mandated to formulate policy, guidelines for administration and implement the activities regarding inputs management.

\section{METHODOLOGY OF THE STUDY}

The study is based on the secondary information available in the Ministry of Agricultural Development and other institutions. The information was collected through published policy documents, progress reports and position papers submitted to Ministry of Finance, National Planning Commission, and Office of Prime Minister and Council of Ministers. Similarly, personal interview using semi-structured questionnaire to the authorized personnel of MoAD was also employed to validate the collected information.

Simple decomposition analysis was also used to assess the effect of area and yield on change in production of paddy, wheat and maize during the period of FY 2065/66 to FY 2071/72.

\section{METHODOLOGY USED FOR DECOMPOSITION ANALYSIS}

$$
\mathrm{Pn}-\mathrm{Po}=(\mathrm{Yn}-\mathrm{Yo}) \mathrm{Ao}+(\mathrm{An}-\mathrm{Ao}) \mathrm{Yo}+(\mathrm{Yn}-\mathrm{Yo})(\mathrm{An}-\mathrm{Ao})
$$

Where, $\mathrm{Yn}=$ average yield of last three years

Yo= average yield of initial three years

$\mathrm{An}=$ average area of last three years

$A o=$ average area of initial three years

$\mathrm{Pn}-\mathrm{Po}=$ change in production

$(\mathrm{Yn}-\mathrm{Yo}) \mathrm{Ao}=$ Yield effect

(An-Ao) Yo= Area effect

$(\mathrm{Yn}-\mathrm{Yo})(\mathrm{An}-\mathrm{Ao})=$ Interaction effect

\section{RESULTS AND DISCUSSIONS}

\section{CHEMICAL FERTILIZER SUBSIDY IN NEPAL (BEFORE 2008/09)}

Introduction of chemical fertilizer in Nepal dates back to early 1950's with the import of Ammonium Sulphate from India by private traders. However, the systematic effort to import chemical fertilizer started with the establishment of Agriculture Inputs Corporation (AIC) under MoAD in 1966.

With the rise in international price of chemical fertilizer during 1970s, GoN decided to introduce price subsidy. AIC used to receive difference between actual cost and selling price as subsidy. Due to growing demand for the fertilizer and increased international prices, financial burden of Government started to creep up. Government's failure to allocate sufficient budget for the subsidy resulted into AIC's loss. AIC became unable to import the quantity as per the demand leading to short supply. Nepal received fertilizer under grant aid from Germany, Canada, Finland and Japan, however, some countries stopped the supply in 1991/92 and others reduced the volume (Shrestha, 2010). 
Till 1997/98, AIC was the only agency for fertilizer trade in the country. The failure of Government to allocate sufficient budget caused reduction in import and distribution of fertilizer. In November, 1997, subsidy was completely removed in DAP and MoP while in Urea subsidy was removed in 1999. It also deregulated the price control. To institutionalize the fertilizer deregulation policy Government promulgated Fertilizer (control) Order, 1997 and National Fertilizer Policy, 2002 that paved the way for private traders to stand at equal footing with AIC. In the same period AIC was terminated to form two companies namely, Agriculture Inputs Company Limited (AICL) responsible for fertilizer business and National Seed Company Limited (NSCL) responsible for seed business under Company Act, 1996(Shrestha, 2010).

\section{CURRENT SUBSIDY SCHEME (2008/09 TILL DATE)}

The deregulation policy did not contribute to smooth supply of fertilizer in the country. Illegal inflow of fertilizers from India was experienced in early periods due to rise in international prices, subsidy provision of India to its farmers and poor purchasing power of Nepalese farmers. Similarly, due to short supply of quality fertilizers to the farmers, they were forced to rely on fertilizer of unidentified and unauthorized quality available in the market. Moreover, in absence of subsidy, higher price of fertilizer led to higher cost of production and poor capacity to compete in the international market. So, to assure the supply of quality fertilizer to the farmers, MoAD approved a proposal by Council of Ministers in November, 2008. In addition, MoAD in coordination with Ministry of Finance (MoF) developed operational modality of the subsidy administration which was endorsed by Government in March, 2009.

\section{FEATURES OF CURRENT SUBSIDY SCHEME (AS PER THE DECISION OF COUNCIL OF MINISTERS)}

$>$ Provision of maintaining selling prices of fertilizer at $20-25 \%$ higher than that of India at five import points (Biratnagar, Birgunj, Bhairahawa, Nepalgunj and Dhangadhi).

$>$ Agriculture Inputs Company Limited (AICL) and Salt Trading Corporation Limited (STCL) are responsible to import and distribute the chemical fertilizer.

$>$ The difference amount between actual cost and subsidized price will be provided as subsidy to AICL and STCL (subsidy administration is on cost sharing basis).

> Provision of subsidy distribution management committee chaired by secretary of MoAD. The committee is responsible for price fixation, fund release and overall monitoring and evaluation of the subsidy program.

> Subsidized fertilizer will be available for 0.75 hectare in hilly districts and 4 hectares in terai districts to the technical requirement of three crops per year.

$>$ Subsidized fertilizer is distributed through offices of AICL, STCL and cooperatives.

$>$ Chief District Officer (CDO) of the respective district chairs the Fertilizer Supply and Distribution Management Committee which is responsible for overall management of fertilizer distribution at district level.

\section{STATUS OF CHEMICAL FERTILIZER SUBSIDY}

The amount of chemical fertilizer imported within country after the promulgation of current subsidy scheme has increased significantly over the years. The import volume has increased from 22.50 thousand Mt in starting year (FY 2065/66) to 278 thousand Mt in FY 2071/72 (Figure 1). 
Figure 1: Amount of chemical fertilizer imported under subsidy scheme

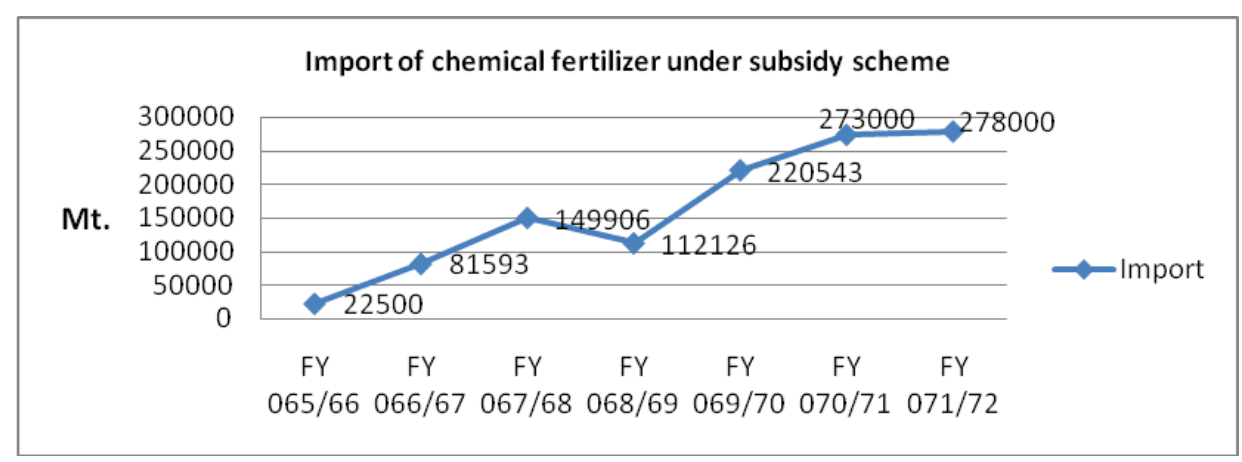

With the rise in import volume, the amount distributed under subsidy has also increased over the years. In FY 2065/66, a total of 7,090 Mt chemical fertilizer was distributed in subsidy throughout the country which increased to 298 thousands Mt in FY 2071/72 (Table 1). The increase in import and distribution indicates that the availability of quality chemical fertilizer has led to increased demand from farmers' side.

Table 1: Amount of chemical fertilizer distributed in subsidy.

(quantity in Mt.)

\begin{tabular}{|l|l|l|l|l|l|l|l|}
\hline Fertilizer/FY & $2065 / 66$ & $2066 / 67$ & $2067 / 68$ & $2068 / 69$ & $2069 / 70$ & $2070 / 71$ & $2071 / 72$ \\
\hline Urea & 5932 & 50489 & 85191 & 97956 & 108553 & 146117 & 190163 \\
\hline DAP & - & 25211 & 22019 & 43146 & 65722 & 81738 & 101797 \\
\hline MoP & - & 2357 & 2821 & 3711 & 2688 & 5023 & 6717 \\
\hline Complexal & 1158 & 3788 & - & - & - & - & - \\
\hline Total & 7090 & $\begin{array}{l}81845 \\
(1054)\end{array}$ & $\begin{array}{l}110031 \\
(34)\end{array}$ & $\begin{array}{l}144813 \\
(31)\end{array}$ & $\begin{array}{l}176963 \\
(22)\end{array}$ & $\begin{array}{l}232878 \\
(31)\end{array}$ & $\begin{array}{l}298677 \\
(28)\end{array}$ \\
\hline
\end{tabular}

(Source: AIMS-MOAD, 2016)

(Figures in the parentheses indicate percent increased compared to previous year.)

After FY 2066/67 the consumption of fertilizer has shown increment of more than $20 \%$ each year compared to the previous year.

\section{FERTILIZER AND NUTRIENT USE STATUS}

The fertilizer consumption per hectare has increased after the implementation of chemical fertilizer subsidy program. Based on the total consumption of chemical fertilzier in FY 2065/66 the fertilizer and nutrient use per hectare was $2.29 \mathrm{~kg}$ and $1.03 \mathrm{~kg}$ which has significantly increased over the 
years and has reached to $96.62 \mathrm{~kg}$ and $50.68 \mathrm{~kg}$ respectively (figure 2). The consumption level is far below compared to that targeted by Agriculture Perspective Plan (APP). APP has targeted nutrient use of $131 \mathrm{~kg} / \mathrm{ha}$ by the end of 2015 . The consumption level is very low compared to that of neighbouring countries as well. Fertilizer use of $147 \mathrm{~kg} / \mathrm{ha}, 176 \mathrm{~kg} / \mathrm{ha}, 166 \mathrm{~kg} / \mathrm{ha}$ and $101 \mathrm{~kg} / \mathrm{ha}$ has been reported in India, Bangladesh, Pakistan and Sri Lanka respectively in 2009 (Bista et al, 2013)

Figure 2: Fertilizer and nutrient use per hectare

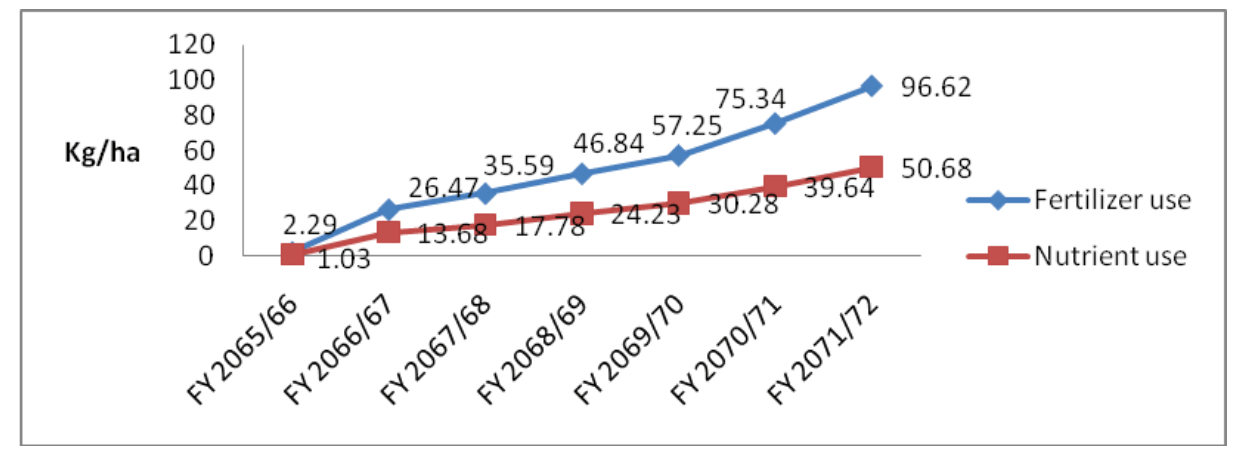

(Source: AIMS, Ministry of Agricultural Development)

The budget allocation in chemical fertilizer subsidy has increased significantly from 366 million rupees in FY 2065/66 to 5.32 billion rupees in FY 2071/72. In the period of 7 years (from FY 2065/66 to FY 2071/72) total expenditure on chemical fertilizer will be 52.29 billion rupees while the subsidy expenditure for the program will be 23.19 billion rupees (Figure 4). Government's ability to allocate budget regularly for the program has resulted smooth supply of chemical fertilizer in the country.

Table 2: Budget description for chemical fertilizer subsidy

\begin{tabular}{|l|r|r|r|}
\hline FY/Description & Cost (in '000 NRs.) & Subsidy (in '000 NRs.) & \multicolumn{1}{l|}{ Subsidy share (\%) } \\
\hline $065 / 66$ & 688087 & 366813 & 53.30 \\
\hline $066 / 67$ & 2819139 & 1370518 & 48.61 \\
\hline $067 / 68$ & 6195372 & 2526380 & 40.78 \\
\hline $068 / 69$ & 5415758 & 3129947 & 57.79 \\
\hline $069 / 70$ & 11468933 & 5171837 & 45.09 \\
\hline $070 / 71$ & 12786106 & 5308772 & 41.51 \\
\hline $071 / 72$ & 12919773 & 5324806 & 41.21 \\
\hline Total & 52293168 & 23199073 & 44.36 \\
\hline
\end{tabular}

(Source: AIMS-MoAD, 2016) 
The subsidy over the year has declined except for the FY 2068/69 (Table 2). The main reason for the decline in subsidy percentage is decline in international prices and fixed subsidized prices of fertilizer maintained by the Government.

\section{ORGANIC FERTILIZER SUBSIDY}

\section{STATUS OF ORGANIC FERTILIZER SUBSIDY}

To minimize the negative consequences of chemical fertilizer and maintain the soil health, Ministry of Agricultural Development started organic fertilizer subsidy program with the promulgation of Organic Fertilizer Subsidy Guideline, 2068. According to the guideline subsidy is provided in organic fertilizer produced in the country and registered as per the Organic and Bio-fertilizer Regulation Guidelines, 2068. The Subsidy Distribution and Management Committee, chaired by the secretary of Ministry of Agricultural Development is responsible for overall administration of organic fertilizer subsidy program including fund release, fixing subsidy rate, price and monitoring of the program. Fertilizer Supply and Distribution Management Committee chaired by Chief District Officer (CDO) of in the district is responsible to look after the distribution, monitoring and evaluation of the program at district level. The subsidized organic fertilizer at famers' level is distributed through AICL, cooperatives and cooperative shops.

The second year of program implementation showed some increment in amount distributed which went on to decrease on following year (Table 3). Despite budget allocation and increase in subsidy percent over the years, the program has not been found to be impressive.

Table 3: Status of Organic fertilizer subsidy

\begin{tabular}{|l|l|l|l|}
\hline Description/FY & $2068 / 69$ & $2069 / 70$ & $2070 / 71$ \\
\hline Quantity purchased (Mt) & 3139 & 1861 & 1900 \\
\hline Actual sales (Mt) & 788 & 3177 & 2615 \\
\hline Cost ('000 NRs.) & 67670 & 39872 & 27084 \\
\hline Subsidy ('000 NRs.) & 39419 & 23123 & 19248 \\
\hline Subsidy percentage & 58.25 & 57.99 & 71.06 \\
\hline
\end{tabular}

(Source: AIMS-MoAD, 2016)

The farmers are interested in chemical fertilizers due to its quick response to the crop. Moreover, practice of using locally available farm yard manure, compost and organic fertilizer is popular among farmers. However, ministry is implementing programs for shed improvement, supporting vermicompost preparation at local level and establishment of organic fertilizer industries throughout the country to promote organic fertilizer.

\section{STATUS OF SEED SUBSIDY}

Subsidy on improved seed was started with the promulgation of Guidelines for subsidy on improved seed in 2068. The Guidelines has made the provision of high level Seed Supply and Distribution Management committee chaired by the secretary of Ministry of Agricultural Development. The 
committee is responsible for overall administration of the program, determination of quantity under subsidy, fund release and monitoring. The program envisages providing subsidy in major cereals, pulse and oilseed; however, the program has been confined to paddy and wheat only. The reason for exclusion of other crops in the scheme is limited availability is quality seeds within country. District Agricultural Inputs Supply Committee chaired by Chief District Officer (CDO) of the respective district is responsible for overall administration, distribution and monitoring of the seed subsidy program at district level. Seed subsidy can be provided in paddy, wheat, maize, millet, lentil, gram, pigeon pea, green gram, pea and mustard. Subsidy scheme has the provision to provide seed for 2.66 ha in terai and 2 ha in hills per year per farmer. The subsidized seed at farmers' level is distributed through dealers of NSCL.

Table 4: Status of Seed subsidy

\begin{tabular}{|l|l|l|l|l|}
\hline Description/FY & $2068 / 69$ & $2069 / 70$ & $2070 / 71$ & $2071 / 72$ \\
\hline Sales Quantity (Mt.) & 579 & 10 & $\begin{array}{l}6550(4769 \text { Mt. wheat and } \\
1781 \text { Mt. paddy) }\end{array}$ & $\begin{array}{l}\text { 7826 (5457 Mt. wheat } \\
\text { and 2369 Mt. Paddy) }\end{array}$ \\
\hline Subsidy ('O00 NRs.) & 6530 & 475 & 111073 & 155379 \\
\hline Subsidy percentage & $25-40$ & 100 & $15-35$ & $30-35$ \\
\hline
\end{tabular}

(Source: AIMS-MOAD, 2016)

The subsidy program on improved seeds has been impressive. The program initiated in FY 2068/69 with the distribution of 579 Mt. improved seeds of paddy which increased to $7826 \mathrm{Mt}$. (5457 Mt. wheat and 2369 Mt. paddy) in FY 2071/72. The program could not function in FY 2069/70, however, in the year only $10 \mathrm{Mt}$ of paddy seeds were distributed freely in flood hit districts of far western region. The subsidy percent in the first year of subsidy program was $25-40 \%$ of market price which was $30-35 \%$ in paddy and $35 \%$ in wheat in FY $2071 / 72$ (Table 4).

\section{EFFECT OF SUBSIDY ON MAJOR CEREAL CROPS}

The decomposition analysis of major cereals (paddy, maize and wheat) shows that the increase in production between the period of FY 2065/66 to FY 2071/72 is due to increase in yield of the crop.

In case of paddy and maize entire increment in production is due to yield effect. In case of wheat increment in production is due to area, yield and interaction of area and yield effect; however the increment is largely due to yield effect which is $82 \%$ (Table 5).

Table 5: Decomposition analysis of paddy, maize and wheat

\begin{tabular}{|l|c|c|c|c|}
\hline Crops & Change in production (Mt.) & Area effect & Yield effect & Interaction effect \\
\hline Paddy & 444236 & -0.43 & 1.49 & -0.06 \\
\hline Maize & 191211 & 0.01 & 0.98 & 0.001 \\
\hline Wheat & 365002 & 0.15 & 0.82 & 0.03 \\
\hline
\end{tabular}

(Source: AIMS-MOAD, 2016)

The yield of crop depends on seed, fertilizer, irrigation and management. Improved seed and quality fertilizer play important role in crop productivity. The smooth supply of chemical fertilizer under 
subsidy scheme and increasing amount of improved seed distribution must have played role for positive yield effect.

Assured supply of fertilizer and improved seeds will have positive impact on production and productivity. The subsidy program has assured the supply of inputs in the country and has impacted positively on production and productivity of crops.

\section{SWOT ANALYSIS OF INPUT SUBSIDY MECHANISM}

\section{STRENGTH}

- Provision of separate section (Agriculture Inputs Management Section) in MoAD for the specific task of fertilizer and seed subsidy.

- Already defined policy framework and guidelines for program implementation.

- The program to support subsidy in Nepal is under First Priority Program (P1) thereby assuring the regular budget allocation.

- Involvement of Agriculture Inputs Company Limited (AICL) and Salt Trading Corporation Limited (STCL) in import and distribution of fertilizers and National Seed Company Limited (NSCL) in seed subsidy administration provides the opportunity to utilize their business expertise.

\section{WEAKNESS}

- Insufficient human resource at bottom level implementation units (DADOs).

- Insufficient number of fertilizer and seed inspectors in DADOs to monitor and regulate the program.

- Lack of separate section in Department of Agriculture and Regional Agricultural Directorate to administer input subsidy program.

- Complicated procurement procedure under public procurement act leading difficulty in timely supply of fertilizer and seed on season.

- Current fertilizer subsidy policy targets cereal crops only.

- The budget allocation is far below compared to the requirement of chemical fertilizer.

- Subsidy is limited only to the Urea, DAP and MoP fertilizers.

- Subsidy on seed is confined to major cereals only.

- Due to undulated geographical terrain and transport facility, the subsidy scheme has not been able to cover the farmers of remote areas.

- Program targets small and marginal farmers only.

\section{OPPORTUNITY}

- Increasing commercialization is demanding more of improved inputs like chemical fertilizer and improved seeds.

- Government is conducting a rigorous feasibility study to establish chemical fertilizer plant within the country.

- Ministry is providing trainings to produce and capacitate more number of fertilizer and seed inspectors for regulatory works.

- Existing network of DADOs and Service center at bottom level to effectively implement the program.

- Involvement of cooperatives for distribution at farmer level makes the distribution mechanism more transparent. 


\section{THREAT}

- Fertilizer supply is entirely dependent on import.

- Price fluctuation of chemical fertilizers in international market.

- Distortion of fertilizer market due to subsidy scheme leading to dismal participation of private sector in the business.

- Increasing use of chemical fertilizers may result to decline in soil health in long term.

- Porous border of Nepal and India possesses threat of drain of subsidized fertilizer to India.

\section{CONCLUSION}

The budget allocation and the amount of chemical fertilizer and seed distributed have increased over the years. In case of organic fertilizer, the program has not been impressive. Organic fertilizer production in Nepal is still in initial phase of commercialization thereby leading to limited choice among the farmers. Moreover, locally available farm yard manure and compost are popular among the farmers which shares large proportion of organic fertilizer consumption. With the experience of slow pace of organic fertilizer subsidy program, MoAD has promulgated Organic Fertilizer Subsidy (district level) Guideline, 2072. As per this provision farmers are independent to purchase the fertilizer of their choice at subsidized rate and the respective District Agriculture Development Office will refund the subsidy amount to the organic fertilizer seller. This is expected to increase the completion among the organic fertilizer producers and helping the farmers to choose the quality fertilizer.

Government's priority for assured supply of seed and fertilizer as well as increased allocation of budget over the year has led to increased supply and consumption of seed and fertilizer in country.

\section{RECOMMENDATION}

$>$ The fertilizer subsidy scheme should cover medium and large farmers also. The minimal participation of private traders and exclusion of large and medium farmers from the subsidy has resulted into unavailability of chemical fertilizer to the large and medium farmers.

$>$ The subsidy scheme focuses for food crops and does not address the requirement for the commercial crops. There should be provision for fertilizer subsidy to commercial crops as well.

$>$ The provision of 4 ha in terai and 0.75 ha in hills looks unfair from regional balance point of view. The area limitation for hill should be increased.

$>$ The current scheme releases subsidy amount to AICL and STCL in advance. The subsidy should be provided in actual sales basis of fertilizer so that burden of Government will be minimized.

$>$ The program of distribution of Farmer Identification Card (Kisan Parichaya Patra) should be tied with the subsidy program. The card will identify small, medium and large farmers. Ministry should look to provide subsidy to all the farmers but in different rates.

> National Fertilizer Policy, 2002 also envisages providing equal opportunity to private and cooperative sectors in fertilizer trade but due to direct involvement of Government in fertilizer trade, private traders are unable to compete. Government should look to introduce a voucher system that is valid for fertilizer and seed purchase by the farmers and based on the purchased amount of fertilizer and/or seed subsidy amount should be refunded to farmers' account.

> AICL and STCL as well as MoAD should maintain a comprehensive data base of total fertilizer sales, regional and district wise distribution as well as monthly distribution pattern so that the data would be handy to analyze the consumption pattern according to season and crop. 
MoAD should maintain the buffer stock of fertilizer as envisaged by the National Fertilizer Policy, 2002.

> The seed subsidy program should be widened to pulses and oilseed crops as well. Besides, purchasing and distributing seed in subsidy, Ministry should look to assure production of quality seeds within country.

$>$ The seed subsidy program is confined to the terai region. So, the program should cover mid hills and high hills regions as well to increase the access to quality seeds.

$>$ The distribution of organic fertilizer should be done at local level through District Agricultural Development offices. The operation at local level will create opportunity to compete the producers thereby leading to increased choice for farmers.

$>$ Ministry should look for the program to support organic fertilizer producing farmers groups and cooperatives to produce at local level.

$>$ As the productivity of crops also depends on other factor along with seed and fertilizer, ministry should look to conduct studies on impact of the seed and fertilizer subsidy on crop production and productivity as well as livelihood of farmers.

\section{REFERENCES}

ABPSD/MoAD, 2013. Statistical Information on Nepalese Agriculture Time Series Information 1999/2000-2011/2012. Government of Nepal, Ministry of Agricultural Development, AgriBusiness Promotion and Statistics Division, Statistics Section, Singhdurbar, Kathmandu, Nepal.

AIMS-MoAD, 2016. Agriculture Inputs Management Section (Annual Progress report), Ministry of Agricultural Development, Singhadurbar, Kathmandu.

APP (1995-2014). Agriculture Perspective Plan (1995-2014). His Majesty's Government of Nepal, National Planning Commission, Singhadurbar, Kathmandu, Nepal.

ADS, 2015. Agriculture Development Strategy (2015-2034). Ministry of Agricultural Development, Singhadurbar, Kathmandu, Nepal

Bista, D.R., Amgai, L.P., and Shrestha, S. 2013. Food security scenario, challenges and agronomic research directions of Nepal in Agronomy Journal of Nepal (Agron JN) vol.3, 2013.

CBS, 2012. National Population and Housing Census 2011 (National Report). Government of Nepal, National Planning Commission Secretariat, Central Bureau of Statistics Kathmandu, Nepal.

CBS, 2013. National Sample Census of Agriculture Nepal 2011/12. National Report. Government of Nepal, National Planning Commission Secretariat, Central Bureau of Statistics Kathmandu, Nepal.

MED/MoAD, 2013. Annual Progress Report. Government of Nepal, Ministry of Agricultural Development, Monitoring and Evaluation Division, Singhdurbar, Kathmandu, Nepal.

MoAD, FAO \& WFP, 2014. Crop situation analysis for 2012/13.

MoF, 2014. Economic survey, Ministry of Finance Nepal

MoF, 2014. Economic Survey. Government of Nepal, Ministry of Finance, Singhdurbar, Kathmandu.

National Seed Vision 2013-2025. Government of Nepal, Ministry of Agricultural Development, National Seed Board, Seed Quality Control Centre, Hariharbhawan, Lalitpur, Nepal

Shrestha, R.K. 2010. Fertilizer Policy Development in Nepal. The Journal of Agriculture and Environment, vol:11. Government of Nepal, Ministry of Agricultural Development, Gender Equity and Environment Division, Singhdurbar, Kathmandu, Nepal. 